\title{
内部に複素環メソゲン単位を含む新規 $\mathbf{A}_{2}+\mathbf{B}_{3}$ 型ハイパーブランチポリマーの 合成および性質
}

\author{
佐藤 守之*1 · 中島 淳*1 · 山口 勲*1
}

（受付 2007 年 5 月 28 日·審査終了 2007 年 8 月 27 日）

\begin{abstract}
要 旨 内部に 1,3,4-チアジアゾールのフェニルスチルベン類似物 (PEPT)をメソゲンとして含む, 構 造の制御された新しい $\mathrm{A}_{2}+\mathrm{B}_{3}$ 型ハイパーブランチ $(\mathrm{HB})$ ポリマーを重縮合により合成し, 液晶性抢よび 光学的性質を調べた. HB ポリマーはPEPT のジオキシジウンデカノール誘導体 $\left(\mathrm{A}_{2}\right)$ とトリメシン酸ト リメチル $\left(\mathrm{B}_{3}\right)$ から, 種々の仕込みモル比 $\left(\mathrm{A}_{2} / \mathrm{B}_{3}\right)$ で合成した. 得られた HB ポリマーは, 仕込み比に応じ た制御末端構造をもつこと抢よび末端 $\mathrm{OH}$ 基のアセチル化処理により, 分子量が上昇することが明らか になった. $\mathrm{A}_{2} / \mathrm{B}_{3}=3 / 2$ の条件で得られたポリマーの平均分子量が最大であった。 また，有機溶媒に対し て良溶解性を示した。いずれの HB ポリマーも， $T_{\mathrm{g}}$ 以上でエナンチオトロピックなスメクチック液晶相 を発現した. UV-vis 抢よび PL スペクトルの測定の結果, UV 吸収抢よび青色の蛍光に基づく最大波長を 示したが, 発光強度は低かった。 また, 対応する線状ポリマーと性質を比較した。
\end{abstract}

\section{1 緒言}

ハイパーブランチポリマー $(\mathrm{HB})$ は，従来の線状ポリ マーとデンドリマーの中間の構造をもつ高分岐状ポリ マーで, 良有機溶媒溶解性および非晶性などの樹状構造 に由来する，特徵的な性質をもつポリマーである1) 3).

一般的に $\mathrm{HB}$ ポリマーは， $\mathrm{A}_{\mathrm{m}} \mathrm{B}_{\mathrm{n}}$ 型モノマーあるいは $\mathrm{A}_{\mathrm{m}}+\mathrm{B}_{\mathrm{n}}$ 型モノマーの逐次反応で製造できるため，デ ンドリマーに比べ短時間および低コストで製造できる， 時間的にもかつ経済的にも有利なポリマーであり, 既 に種々の機能を備えた数多くの HB ポリマーが報告され ている4) 7).

一方，主鎖にカラミチックメソゲン単位をもつ線状ポ リマーは，板状のメソゲン単位に由来する特徵的なサー モトロピック液晶相を発現し，その液晶性はメソゲン単 位の配向性に依存することが知られており，構造と液晶 性の関係が既に詳細に検討されている $\left.{ }^{8)} 22\right)$. しかし， 分岐構造をもつ液晶性デンドリマーや HB ポリマーの合 成と液晶性についての報告は，液晶性の線状ポリマーに 比べて少なく23) 28), HB ポリマーの構造と液晶性の関 係についてはほとんど明らかになっていない。現在まで に報告されている液晶性 HB ポリマーは，そのほとんど が $\mathrm{AB}_{2}$ 型の $\mathrm{HB}$ ポリマーであり23) 26)，報告されている $\mathrm{A}_{2}+\mathrm{B}_{3}$ 型の液晶性ポリマーは, 筆者らの知る限り, 筆

*1 島根大学総合理工学部(画690-8504 松江市西川津町 1060)
者らの 1,3,4-チアジアゾール $(\mathrm{TD})^{7)}$ および 2-フェニル ベンゾチアゾール $(\mathrm{PBT})^{28)}$ に由来する液晶性 HB ポリ マーと Murali らのベンジリデン単位に由来する HB ポ リマーだけである27).

本研究では, 構造の制御された $\mathrm{A}_{2}+\mathrm{B}_{3}$ 型 $\mathrm{HB}$ ポリ マーと対応する線状ポリマーの液晶性を比較検討する ことを目的として, TDのフェニルスチルベン類似物 (PEPT)のジオキシジウンデカノール誘導体 (HUHUT) $\left(\mathrm{A}_{2}\right)(2)$ とトリメシン酸トリメチル $\left(\mathrm{B}_{3}\right)(5)$ から種々の 仕込みモル比 $\left(\mathrm{A}_{2} / \mathrm{B}_{3}\right)$ で, メソゲン単位として PEPT をもつ, 構造の制御された $\mathrm{A}_{2}+\mathrm{B}_{3}$ 型液晶性 $\mathrm{HB}$ ポリ マー (6) (Scheme 2) を合成し，それらの構造と液晶性の 関係を明らかにした。 また，HB ポリマー（6）の末端 $\mathrm{OH}$ 基を無水酢酸でアセチル化処理し, 末端処理化 $\mathrm{HB}$ ポリマー(7)の液晶性に及ぼす末端基の影響を調べた (Scheme 3). さらに, $\mathrm{A}_{2}+\mathrm{B}_{3}$ 型 $\mathrm{HB}$ ポリマー(6)に対応 する線状ポリマーを合成(4) (Scheme 1) し, それらの液 晶性を比較検討した。 また, 線状ポリマー(4)と HB ポ リマー(6) および(7)の光学的性質を明らかにした.

\section{2 実験}

\section{1 原料}

トリメシン酸トリメチル $\left(\mathrm{B}_{3}\right.$ モノマー) $(5)$ は, 微量の 濃硫酸存在下でトリメシン酸とメタノールから合成した 後, アセトンで 2 回再結晶して使用した $(\mathrm{mp}: 159 \sim 160$ $\left.{ }^{\circ} \mathrm{C}\right) . \mathrm{A}_{2}$ モノマー(2)の合成原料の $\operatorname{HPHPT}(1)$ は, 前報 
佐藤·中島·山口

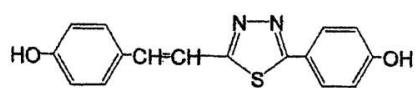

(1)

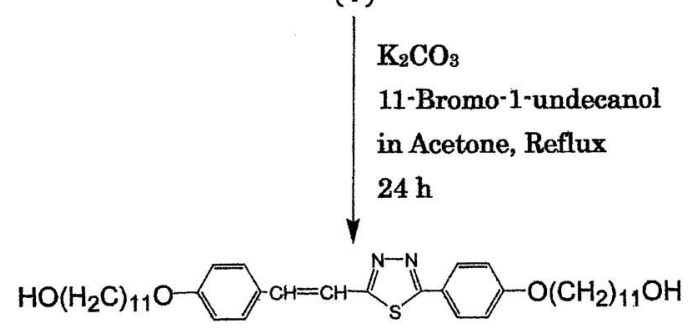

$\mathrm{A}_{2}$ (2)

(2)

$+\mathrm{H}_{3} \mathrm{COOC}-\mathrm{R}-\mathrm{COOCH}_{3}$

(3)
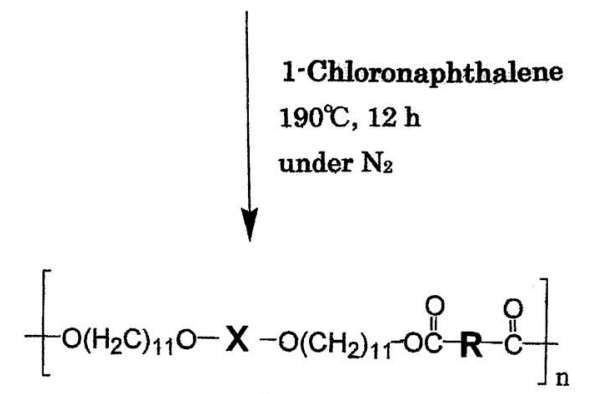

(4)

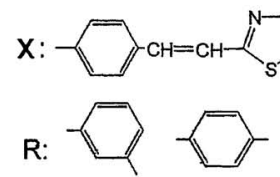

(a)

(b) $-\left(\mathrm{CH}_{2}\right)_{4}--\left(\mathrm{CH}_{2}\right)_{8}-$

(c)

(d)

Scheme 1.

の方法に従って合成した ${ }^{21)}$.

2.2 2-\{2-[4-(11-ヒドロキシウンデシロキシフェニ ル) ]エテニル\}-5-[4-(11-ヒドロキシウンデシロ キシフェニル) ]-1,3,4-チアジアゾール

(HUHUT) ( $\mathbf{A}_{2}$ モノマー) (2)の合成

$\operatorname{HPHPT}(1)$ ( $2 \mathrm{mmol}, 0.593 \mathrm{~g})$ と炭酸カリウム $(50$ $\mathrm{mmol}, 6.91 \mathrm{~g})$ を乾燥アセトン $(100 \mathrm{~mL})$ 中で 30 分間還 流した. 反応混合物を放冷後, アセトン混合物に11-ブ ロモ-1-ウンデカノール $(4.2 \mathrm{mmol}, 1.06 \mathrm{~g})$ を加え, さら に 24 時間還流した. 反応終了後, 反応混合物を大過剰 の水に投入し, 生成沈殿物をろ過した. 得られた粗結 晶を水で十分洗浄後, クロロホルムで 3 回再結晶した. 目的物 (HUHUT) をろ過後, $60^{\circ} \mathrm{C}$ で 24 時間減圧乾燥し た. 収率 : $63 \%$. $\mathrm{Cr} 126^{\circ} \mathrm{C}\left(94 \mathrm{~J} \cdot \mathrm{g}^{-1}\right) \mathrm{Sc} 174^{\circ} \mathrm{C}(1.8 \mathrm{~J}$. $\left.\mathrm{g}^{-1}\right) \mathrm{I}$.

${ }^{1} \mathrm{H} \mathrm{NMR} \quad\left(\mathrm{CDCl}_{3}\right): \delta=7.93 \sim 6.95 \quad(10 \mathrm{H}, \mathrm{m}), 4.01$ $(4 \mathrm{H}, \mathrm{t}), 3.89(2 \mathrm{H}, \mathrm{s}), 3.65(4 \mathrm{H}, \mathrm{t}), 1.83 \sim 1.30 \mathrm{ppm}$
$(36 \mathrm{H}, \mathrm{m})$.

FT IR $(\mathrm{KBr}): v=3360$ (OH 伸縮振動), 2935，2919, 2848 ( $\mathrm{CH}$ 伸縮振動), $1620(\mathrm{C}=\mathrm{C}), 1405$ (チアジアゾー ル), $1255,1173 \mathrm{~cm}^{-1}$ (C-O-C).

$\mathrm{C}_{38} \mathrm{H}_{56} \mathrm{~N}_{2} \mathrm{O}_{2} \mathrm{~S}(636.9)$ : 計算值 : C 71.65\%, H 8.86\%, N $4.39 \%$, 実測值 : C 71.42\%, H 8.50\%, N 4.85\%.

\section{3 線状ポリマー(4)の合成}

HUHUT (2) (0.4 mmol, $0.255 \mathrm{~g})$ と各種ジメチルエス テル誘導体 $(3)$ (0.4 mmol) を, 触媒の酸化ジブチルスズ $(5 \mathrm{mg})$ の存在下, 1-クロロナフタレン $(1.5 \mathrm{~mL})$ 中, 窒素 雾囲気下, $190^{\circ} \mathrm{C}$ で 12 時間反応した. 重合後, 反応混 合物にジクロロ酢酸 $(2 \mathrm{~mL})$ を加えて溶解したポリマー 溶液を，メタノール $(150 \mathrm{~mL})$ に投入して再沈殿した。 万過した沈殿物を水 $(200 \mathrm{~mL})$ で十分洗浄し, 万過後, さらにメタノールで 1.5 時間, 3 回煮沸洗浄した. 生成 ポリマーを $60^{\circ} \mathrm{C} て ゙ 24$ 時間減圧乾燥した (Scheme 1).

$2.4 \mathrm{~A}_{2}+\mathrm{B}_{3}$ 型 $\mathrm{HB}$ ポリマー(6)の合成 所定の仕込みモル比 $\left(\mathrm{A}_{2} / \mathrm{B}_{3}=3 / 1,2 / 1,3 / 2,1 / 1\right.$ およ び 1/3)の $\mathrm{A}_{2}$ モノマー(HUHUT) (2) (0.5 mmol, 0.159 g) と $\mathrm{B}_{3}$ モノマー $(5)$ を, 触媒の酸化ジブチルスズ $(2.5$ $\mathrm{mg})$ の存在下, 1-クロロナフタレン $(5.6 \mathrm{~mL})$ 中, 窒素雾 囲気下, $190^{\circ} \mathrm{C}$ で 12 時間重縮合反応した. 反応終了 後, 反応溶液を大過剰の $n$-ヘキサンに投入し, $\mathrm{HB}$ ポリ マー（6）を再沈殿した. 万過した生成ポリマーを水打よ びメタノールで洗浄後, さらに $150 \mathrm{~mL}$ の $n$-ヘキサン中 で 3 回煮沸洗浄した. 目的の HB ポリマーをろ過後, 60 ${ }^{\circ} \mathrm{C}$ で 24 時間減圧乾燥した (Scheme 2).

$2.5 \mathbf{A}_{2}+\mathbf{B}_{3}$ 型 $\mathrm{HB}$ ポリマー末端の無水酢酸による処 理 (7)

$\mathrm{A}_{2} / \mathrm{B}_{3}$ の仕込みモル比が，3/1 および $2 / 1$ の条件で重 合した HB ポリマー(6)の反応溶液に, 無水酢酸 $(5 \mathrm{~mL})$ およびピリジン $(0.2 \mathrm{~mL})$ を加え, 6 時間還流した. 反応 溶液を放冷後, $n$-ヘキサン $(150 \mathrm{~mL})$ に投入し, $\mathrm{HB}$ ポ リマーを再沈殿した。沈殿物をろ過後, 水打よびメタ ノールで十分洗浄した. 再度沈殿物をろ過後, $n$-ヘキ サン中で 1.5 時間, 煮沸洗浄した. 得られた末端処理 $\mathrm{HB}$ ポリマー (7) をろ過後, $60^{\circ} \mathrm{C}$ で 24 時間減圧乾燥した (Scheme 3).

\section{6 測定}

FT IR スペクトルおよび ${ }^{1} \mathrm{H}$ NMR スペクトル測定, サイズ排除クロマトグラフィー (SEC)による分子量測 定, DSC 測定, X線回折, 偏光顕微鏡による光学組織 の観察，および UV-vis および PL スペクトル測定は， 既報の方法に従って行った7),13) 22). 


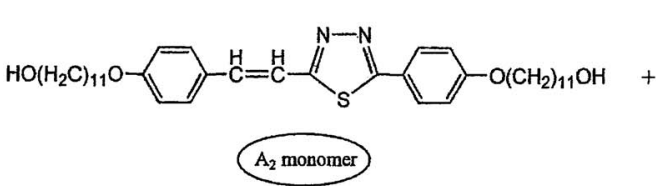

(2)

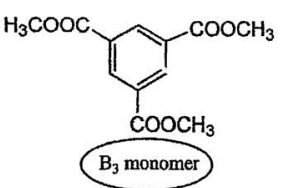

(5)

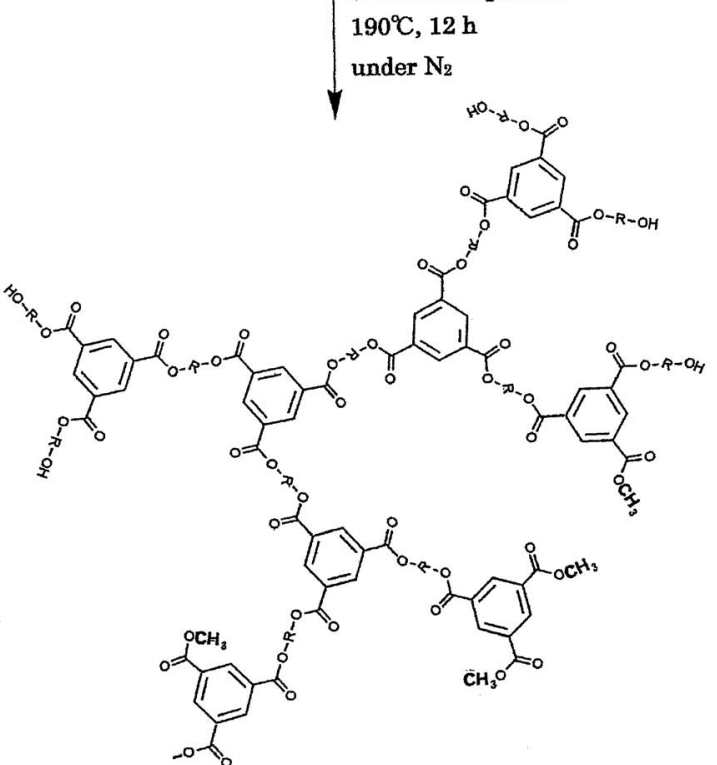

(6)

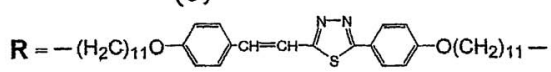

Scheme 2.

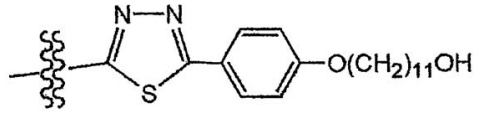

(6)

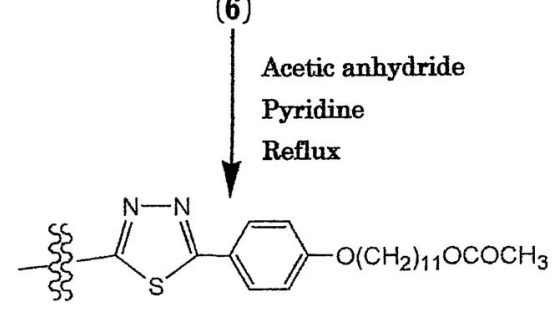

(7)

Scheme 3.

\section{3 結果と考察}

3.1 線状ポリマー(4), および HB ポリマー(6)およ び(7)の合成

PEPT 単位から成る線状ポリマー(4), および HB ポ リマー(6) 抢よび (7)を高温溶液重縮合によって合成し た。最初に線状ポリマー(4)を実験の部に示す条件で合 成した. Table 1 に示すように, ジクロロ酢酸中 $(0.20 \mathrm{~g}$. $\left.\mathrm{dL}^{-1}\right), 30^{\circ} \mathrm{C}$ での固有粘度 $\eta_{\mathrm{inh}}$ が $0.26 \sim 0.30\left(\mathrm{dL} \cdot \mathrm{g}^{-1}\right)$
のポリマー(4)が 79\%〜86\%の收率で得られた。これら のポリマー(4)は, クロロホルムやジクロロ酢酸のよ うな有機溶媒に可溶であった。元素分析值は計算値と 一致した.

次に, これらの線状の主鎖型液晶ポリマー(4)の合成 結果抢よび筆者らの既報》の知見を参考にして, 種々の 仕込反モル比 $\left(\mathrm{A}_{2} / \mathrm{B}_{3}=3 / 1,2 / 1,3 / 2,1 / 1\right.$ 抢よび $\left.1 / 3\right)$ の PEPT のジオキシジウンデカノール誘導体 (HUHUT) $\left(\mathrm{A}_{2}\right.$ モノマー) (2) とトリメシン酸トリメチル $\left(\mathrm{B}_{3}\right.$ モ) マー)(5)から, $\mathrm{A}_{2}+\mathrm{B}_{3}$ 型 $\mathrm{HB}$ ポリマー(6)の合成を試及 た(Scheme 2).しかし, 線状ポリマー(4)の合成条件と 同じ反応濃度では, 反応過程でゲル化が起き不溶不融 のポリマーが生成するため, 溶媒として1-クロロナフ タレンを用いて, 線状ポリマーの反応濃度と比べ, より 低濃度 (反応濃度 : HUHUT を基準にして $0.0893 \mathrm{~mol}$ • $\left.\mathrm{L}^{-1}\right)$ の条件下で重縮合を行った。 その結果, メソゲン として PEPT を内部に持つ, 数平均分子量 $M_{\mathrm{n}} か ゙ 1700$ 〜 7000 の新規 $\mathrm{A}_{2}+\mathrm{B}_{3}$ 型液晶性 $\mathrm{HB}$ ポリマー(6)を合成 することに成功した. 合成結果を Table 2 に示す.

得られた HB ポリマー(6)の FT IR スペクトルには線 状ポリマー(4) と類似の吸収が みられ，エステル $\mathrm{C}=\mathrm{O}$ が $1730 \mathrm{~cm}^{-1}$ 付近に, C-O-C が $1245 \sim 1256 \mathrm{~cm}^{-1}$ に, 
佐藤 · 中島 $\cdot$ 山口

Table 1. Characterization of linear polymers (4)

\begin{tabular}{|c|c|c|c|c|c|c|c|}
\hline \multirow{2}{*}{ No. } & \multirow{2}{*}{$\begin{array}{l}\text { Yield } \\
(\%)\end{array}$} & \multirow{2}{*}{$\begin{array}{c}\eta_{\text {inh }^{\mathrm{a}}} \\
\left(\mathrm{dL} \cdot \mathrm{g}^{-1}\right)\end{array}$} & \multirow{2}{*}{$\begin{array}{l}\text { Formula } \\
\text { (Weight) }\end{array}$} & \multicolumn{4}{|c|}{ Elemental analysis } \\
\hline & & & & & $\mathrm{C}(\%)$ & $\mathrm{H}(\%)$ & $\mathrm{N}(\%)$ \\
\hline \multirow[t]{2}{*}{$4 \mathrm{a}$} & \multirow[t]{2}{*}{84} & \multirow[t]{2}{*}{0.30} & \multirow{2}{*}{$\begin{array}{c}\left(\mathrm{C}_{46} \mathrm{H}_{58} \mathrm{~N}_{2} \mathrm{O}_{6} \mathrm{~S}\right)_{n} \\
(767.0)_{n}\end{array}$} & Calc & 72.03 & 7.02 & 3.65 \\
\hline & & & & Found & 71.15 & 7.00 & 3.80 \\
\hline \multirow[t]{2}{*}{$4 \mathrm{~b}$} & \multirow[t]{2}{*}{86} & \multirow[t]{2}{*}{0.27} & \multirow{2}{*}{$\begin{array}{c}\left(\mathrm{C}_{46} \mathrm{H}_{58} \mathrm{~N}_{2} \mathrm{O}_{6} \mathrm{~S}\right)_{n} \\
(767.0)_{\mathrm{n}}\end{array}$} & Calc & 72.03 & 7.02 & 3.65 \\
\hline & & & & Found & 71.95 & 7.22 & 3.90 \\
\hline \multirow[t]{2}{*}{$4 \mathrm{c}$} & \multirow[t]{2}{*}{79} & \multirow[t]{2}{*}{0.29} & \multirow{2}{*}{$\begin{array}{c}\left(\mathrm{C}_{44} \mathrm{H}_{62} \mathrm{~N}_{2} \mathrm{O}_{6} \mathrm{~S}\right)_{n} \\
(747.0)_{n}\end{array}$} & Calc & 70.04 & 8.37 & 3.75 \\
\hline & & & & Found & 70.07 & 8.00 & 4.19 \\
\hline \multirow[t]{2}{*}{$4 d$} & \multirow[t]{2}{*}{83} & \multirow[t]{2}{*}{0.26} & \multirow{2}{*}{$\begin{array}{c}\left(\mathrm{C}_{48} \mathrm{H}_{70} \mathrm{~N}_{2} \mathrm{O}_{6} \mathrm{~S}\right)_{\mathrm{n}} \\
(803.1)_{\mathrm{n}}\end{array}$} & Calc & 71.78 & 8.79 & 3.49 \\
\hline & & & & Found & 71.00 & 8.18 & 3.63 \\
\hline
\end{tabular}

a) Measured at a concentration of $0.2 \mathrm{~g} \cdot \mathrm{dL}^{-1}$ in dichloroacetic acid at $30^{\circ} \mathrm{C}$.

Table 2. Characterization of HB polymers (6) and (7) ${ }^{\text {a) }}$

\begin{tabular}{cccccc}
\hline \hline No. & $\begin{array}{c}\text { Molar ratio } \\
\mathrm{A}_{2} / \mathrm{B}_{3}\end{array}$ & $\begin{array}{c}\text { Yield } \\
(\mathrm{g})\end{array}$ & $M_{\mathrm{n}} \mathrm{c}^{\mathrm{c}}$ & $M_{\mathrm{w}} / M_{\mathrm{n}}{ }^{\mathrm{c})}$ & $\begin{array}{c}\left.\eta_{\text {inh }} \mathrm{d}\right) \\
\left(\mathrm{dL} \cdot \mathrm{g}^{-1}\right)\end{array}$ \\
\hline $6 \mathrm{a}$ & $3 / 1$ & 0.144 & 2400 & 1.91 & 0.15 \\
$6 \mathrm{~b}$ & $2 / 1$ & 0.151 & 3600 & 1.82 & 0.22 \\
$6 \mathrm{c}$ & $3 / 2$ & 0.143 & 7000 & 5.59 & 0.29 \\
$6 \mathrm{~d}$ & $1 / 1$ & 0.141 & 2400 & 1.97 & 0.18 \\
$6 \mathrm{e}$ & $1 / 3$ & 0.197 & 1700 & 1.93 & 0.13 \\
$7 \mathrm{a}^{\mathrm{b})}$ & $3 / 1$ & 0.121 & 3000 & 2.23 & - \\
$7 \mathrm{~b}^{\mathrm{b})}$ & $2 / 1$ & 0.118 & 6100 & 2.51 & - \\
\hline
\end{tabular}

a) Reaction time: $12 \mathrm{~h}$, temperature: $190^{\circ} \mathrm{C}$, solvent: 1-chloronaphthalene $(5.6 \mathrm{~mL})$. Momomer $\left(\mathrm{A}_{2}\right)$ of $0.5 \mathrm{mmoL}(0.159 \mathrm{~g})$ was fed in the presence of $n$-butyltin oxide $(2.5 \mathrm{mg})$ as a catalyst. b) Acetic anhydride $(5 \mathrm{~mL})$ and pyridine $(0.2 \mathrm{~mL})$ were added to the reaction solutions of HB polymers (6). Reaction time: $6 \mathrm{~h}$, temperature: reflux. ${ }^{c}$ Measured in chloroform using polystyrene as a standard; $M_{\mathrm{n}}$ : number average molecular weight, $M_{\mathrm{w}} /$ $M_{\mathrm{n}}$ : molecular weight distribution. d) Measured at a concentration of $0.2 \mathrm{~g} \cdot \mathrm{dL}^{-1}$ in dichloroacetic acid at $30^{\circ} \mathrm{C}$.

$\mathrm{CH}$ 伸縮振動が 2922〜2924, $2852 \mathrm{~cm}^{-1}$ にそれぞれみら れた．（6a）（6c)では未反応末端 $\mathrm{OH}$ 基の伸縮振動に 由来する吸収が $3200 \sim 3500 \mathrm{~cm}^{-1}$ にみられた。 また, $\mathrm{HB}$ ポリマー (6)の ${ }^{1} \mathrm{H}$ NMR スペクトル (Figure 1) も 線状ポリマー(4)のそれと似て抢り， $\mathrm{A}_{2}$ ユニットの芳 香族環および $\operatorname{trans} \mathrm{CH}=\mathrm{CH}$ のプロトンシグナルが $6.80 \sim 7.83 \mathrm{ppm}, \mathrm{B}_{3}$ ユニットが $8.78 \mathrm{ppm}, \mathrm{OCH}_{2}$ が 3.95 〜3.98 ppm, $\mathrm{CH}_{2} \mathrm{OC}(\mathrm{O})$ のシグナルが $4.30 \sim 4.35 \mathrm{ppm}$, $\left(\mathrm{CH}_{2}\right)_{9}$ のシグナルが $1.18 \sim 1.73 \mathrm{ppm}, \mathrm{B}_{3}$ 末反応末端の $\mathrm{C}(\mathrm{O}) \mathrm{OCH}_{3}$ のシグナルが $3.91 \mathrm{ppm}$ にそれぞれみられ, 仕込久モル比 $\left(\mathrm{A}_{2} / \mathrm{B}_{3}\right)$ に応じてプロトンシグナル強度が

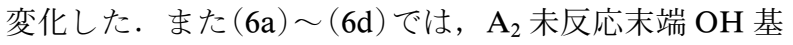
に隣接する $\mathrm{CH}_{2}$ 基のシグナルが $3.58 \sim 3.62 \mathrm{ppm}$ にみら れたＦT IR スペクトルにおいても，吸收強度は仕込み モル比 $\left(\mathrm{A}_{2} / \mathrm{B}_{3}\right)$ に応じて変化しており,これらのスペ クトルデータから $\mathrm{A}_{2}$ が過剰の $\mathrm{HB}$ ポリマー $(6 \mathrm{a})$ および (6b)，抢よびポリマー（6c) および $(6 \mathrm{~d})$ では末端 $\mathrm{OH}$ 基，また $(6 \mathrm{a}) 〜(6 \mathrm{e})$ では $\mathrm{B}_{3}$ の末反応末端メチルエステ ル基が存在していることがわかる.（6a)および $(6 \mathrm{~b})$ を無 水酢酸で処理することにより末端 $\mathrm{OH}$ 基がアセチル化 され (Scheme 3), FT IR スペクトルの $3200 \sim 3500 \mathrm{~cm}^{-1}$ 付近の $\mathrm{OH}$ 基は消失した. しかし, アセチル基の $\mathrm{C}=\mathrm{O}$ に基づく吸収は明確には確認できなかった。 ${ }^{1} \mathrm{H}$ NMR スペクトル(Figure 1)に抢いても，3.58〜3.62 ppmの未 反応末端 $\mathrm{OH}$ 基に隣接する $\mathrm{CH}_{2}$ 鎖によるシグナルは消 失し, $\mathrm{HB}$ ポリマー(7a)抢よび(7b)では, 新たにアセチ ル基 $\mathrm{OC}(\mathrm{O}) \mathrm{CH}_{3}$ に由来するシグナルが， $2.02 \mathrm{ppm}$ に出 現した.

これらの HB ポリマー(6)は, 有機溶媒に対する溶解 性が高く, 線状ポリマー(4)に比べクロロホルムおよ びジクロロ酢酸に対する溶解性が向上したが， $\mathrm{A}_{2}$ モノ マーの過剰な $\mathrm{HB}$ ポリマー $(6 \mathrm{a})$ 抢よび $(6 \mathrm{~b}) て ゙ は \mathrm{~B}_{3}$ が過 剰なポリマー $(6 \mathrm{e})$ よりも溶解性は低かった. Table 2 か らわかるように, クロロホルム中での HB ポリマー (6) の $M_{\mathrm{n}}$ とジクロロ酢酸中 $\left(30^{\circ} \mathrm{C}, \mathrm{C}=0.2 \mathrm{~g} \cdot \mathrm{dL}^{-1}\right)$ での $\eta_{\mathrm{inh}}$ は, $\mathrm{A}_{2} / \mathrm{B}_{3}$ の仕込みモル比に応じて変化しており $\left(\eta_{\mathrm{inh}}=\right.$ $\left.0.13 \sim 0.29 \mathrm{dL} \cdot \mathrm{g}^{-1}\right), \mathrm{A}_{2} / \mathrm{B}_{3}=3 / 2, つ$ り, $\mathrm{A}_{2}$ と $\mathrm{B}_{3}$ の 官能基数が同じ仕込みモル比の $\mathrm{HB}$ ポリマー $(6 \mathrm{c})$ で最大 となった.これは, Floryの理論から予想される結果と 一致している29). また, 末端アセチル化処理の結果を Table 2 に示す. Table 2 から明らかなように, 処理後 の $\mathrm{HB}$ ポリマー $(7 \mathrm{a})$ および $(7 \mathrm{~b})$ の $M_{\mathrm{n}}$ 值は，それぞれ 3000 および 6100 で，いずれも処理前の HB ポリマー (6a) および $(6 \mathrm{~b})$ の $M_{\mathrm{n}}$ 值より高いことがわかる. また， クロロホルムに対する溶解性も処理前より向上した．こ れらの知見は, 末端処理により末端 $\mathrm{OH}$ 基の凝集が抑 制されたために, HB ポリマー鎖の溶液中での広がりが 拡大し， $\eta_{\text {inh }}$ が上昇したことおよび溶解性が向上したこ とを示すと推定される. $\mathrm{HB}$ ポリマー(6)の $\eta_{\mathrm{inh}}$ は， $\mathrm{A}_{2} /$ $\mathrm{B}_{3}=3 / 2$ の $\mathrm{HB}$ ポリマー $(6 \mathrm{c})$ に抢いて, 対応する線状ポ リマー(4) とほぼ同じ值であるが，仕込みモル比が $\mathrm{A}_{2}$ あるいは $\mathrm{B}_{3}$ が過剰な $\mathrm{HB}$ ポリマー $(6 \mathrm{a})$ 抢よび $(6 \mathrm{~b})$, あ るいは (6e)では線状ポリマー(4)より低かった. 


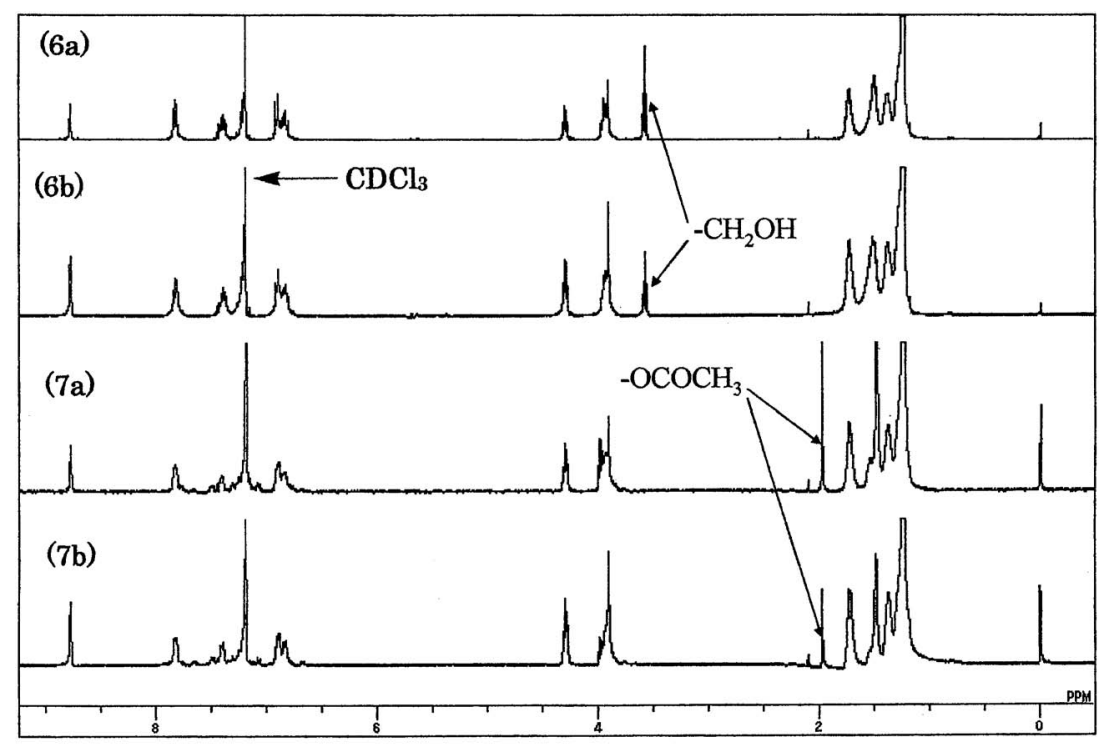

$\delta$ [ppm]

Figure 1. ${ }^{1} \mathrm{H}$ NMR spectra of $\mathrm{HB}$ polymers $(6 \mathrm{a}),(6 \mathrm{~b}),(7 \mathrm{a})$ and $(7 \mathrm{~b})$ in $\mathrm{CDCl}_{3}$.

上述の ${ }^{1} \mathrm{H}$ NMR スペクトルデータから，(6a) および (6b)の構造解析および $M_{\mathrm{n}}$ 值の算出を試みた. しかし, 反応が理想的に進行した場合と比較して，(6a) および (6b)の $\mathrm{A}_{2}$ ユニット $/ \mathrm{B}_{3}$ ユニット比は, $6 \mathrm{a}=3.17$ (推定值 3 ) 抢よび $6 \mathrm{~b}=2.32$ (推定值 2) で，いずれも推定值とは異 なるばかりではなく, $\mathrm{A}_{2}$ 末反応末端 $\mathrm{OH}$ 基数 $(6 \mathrm{a}=2.89$ 抢よび $6 \mathrm{~b}=2.48)$ も推定值 $(6 \mathrm{a}=3$ および $6 \mathrm{~b}=\mathrm{X}+1, \mathrm{X}$ : $\mathrm{A}_{2}$ ユニット数) とは異なっていた．これらの知見は， (6a) 抢よび $(6 \mathrm{~b})$ が分岐鎖以外に環状鎖を含む複雑な構 造をもつポリマーである ${ }^{6), 30)}$ ，ことを示唆すると推定さ れる。したがって，ポリマーの明確な構造と正確で定量 的な $M_{\mathrm{n}}$ 值を算出することは困難であり，環状鎖の数が 確定できないため(比較のために SEC 実測値を測定した が)， $M_{\mathrm{n}}$ の算出は不可能と考えられる．しかし，HB ポ リマーの分子量は仕込みモル比に応じて変化しており， 末端に反応性官能基をもつ，HB ポリマーが生成してい ることが定性的に確認された。

このように本研究では, $\mathrm{A}_{2}$ モノマーと $\mathrm{B}_{3}$ モノマーの 仕込みモル比通りに反応が進行していないことが示唆さ れたが，仕込みモル比に応じて，末端に官能基を持ち， ポリマー鎖の広がりが制御された，カラミチックメソゲ ン単位のPEPTを内部に含む $\mathrm{A}_{2}+\mathrm{B}_{3}$ 型 $\mathrm{HB}$ ポリマー

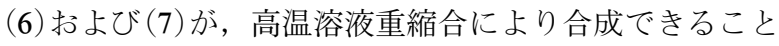
が明らかとなった。

\section{2 液晶性}

PEPT 構造をカラミチックメソゲン単位として含む線 状ポリマー(4)，抢よび HB ポリマー(6) 抢よび(7)の サーモトロピック液晶性を比較検討した。

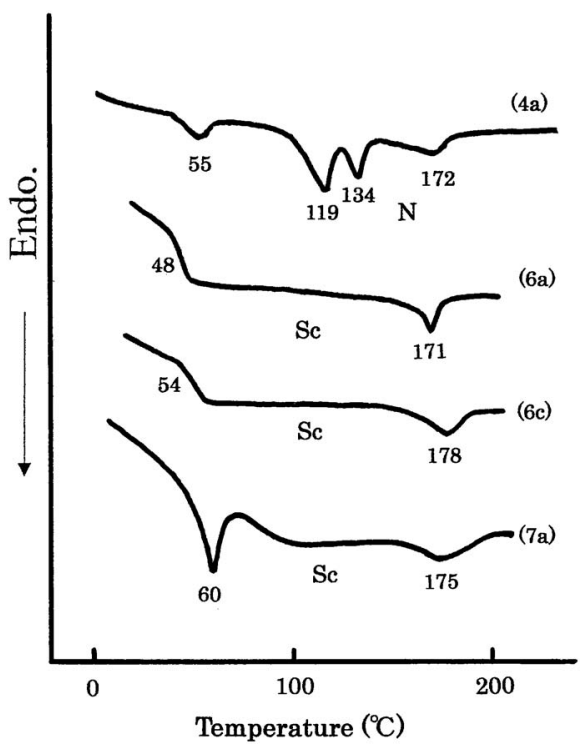

Figure 2. DSC curves of linear polymer (4a), and HB polymers $(6 a),(6 c)$ and $(7 a)$ of the second heating scans.

線状ポリマー $(4 \mathrm{a})$ の 2 回目の加熱時の DSC 曲線を Figure 2 に例示する.いずれのポリマー(4)においても 二つ以上の吸熱ピークがみられ, 冷却時にも対応する発 熱ピークが観察された．偏光顕微鏡観察により，高温側 の二つのピーク $\left(109 \sim 138^{\circ} \mathrm{C}\left(T_{\mathrm{m}}\right)\right.$ および $153 \sim 181{ }^{\circ} \mathrm{C}$ $\left.\left(T_{\mathrm{i}}\right)\right)$ の間で，いずれのモノマー $(3)$ からのポリマー $(4)$ の場合も, 安定なエナンチオトロピックなサーモトロ ピック液晶相 (シュリーレンおよび砂状組織)を形成す ることが確認された。テトラメチレン鎖をもつポリマー 
佐藤 $\cdot$ 中島 $\cdot$ 山口

Table 3. Phase transition temperatures and thermodynamic data of linear polymers (4) and HB polymers (6) and (7) during the second heating $\operatorname{scan}^{\mathrm{a})}$

\begin{tabular}{ccccccccl}
\hline \hline No. & $\begin{array}{c}T_{\mathrm{g}} \\
\left({ }^{\circ} \mathrm{C}\right)\end{array}$ & $\begin{array}{c}T_{\mathrm{k}} \\
\left({ }^{\circ} \mathrm{C}\right)\end{array}$ & $\begin{array}{c}T_{\mathrm{m}} \\
\left({ }^{\circ} \mathrm{C}\right)\end{array}$ & $\begin{array}{c}\Delta H_{\mathrm{m}} \\
\left(\mathrm{J} \cdot \mathrm{g}^{-1}\right)\end{array}$ & $\begin{array}{c}T_{\mathrm{i}} \\
\left({ }^{\circ} \mathrm{C}\right)\end{array}$ & $\begin{array}{c}\Delta H_{\mathrm{i}} \\
\left(\mathrm{J} \cdot \mathrm{g}^{-1}\right)\end{array}$ & $\begin{array}{c}\Delta T \\
\left({ }^{\circ} \mathrm{C}\right)\end{array}$ & LC phase \\
\hline 4a & 55 & 119 & 134 & 23.4 & 172 & 28.0 & 38 & Nematic \\
$4 \mathrm{~b}$ & - & - & 138 & 70.4 & 181 & 58.5 & 43 & Nematic \\
$4 \mathrm{c}$ & - & 97 & 109 & 39.1 & 174 & 45.2 & 65 & Smectic C \\
$4 \mathrm{~d}$ & - & 113 & 129 & 10.5 & 153 & 25.7 & 24 & Smectic C \\
$6 \mathrm{a}$ & 48 & - & - & - & 171 & 2.64 & 123 & Smectic C \\
$6 \mathrm{~b}$ & 55 & - & - & - & 168 & 6.58 & 113 & Smectic C \\
$6 \mathrm{c}$ & 54 & - & - & - & 178 & 6.54 & 124 & Smectic C \\
6d & 49 & - & - & - & 145 & 5.70 & 96 & Smectic A \\
6e & 43 & - & - & - & 115 & 4.79 & 72 & Smectic A \\
7a & 60 & - & - & - & 175 & 5.42 & 115 & Smectic C \\
$7 \mathrm{c}$ & 40 & - & 59 & 4.59 & 180 & 4.33 & 121 & Smectic C \\
\hline
\end{tabular}

a) $T_{\mathrm{g}}$ : glass transition temperature, $T_{\mathrm{k}}$ : solid-to-solid transition temperature, $T_{\mathrm{m}}$ : solid-to-LC phase transition temperature, $T_{\mathrm{i}}$ : LC phase-to-isotropization transition temperature, $\Delta T=T_{\mathrm{i}}-T_{\mathrm{m}}$ : LC temperature range.

(4c) が，一番安定な液晶相を形成した $\left(\Delta T=65^{\circ} \mathrm{C}\right)$. ポ リマー(4)，(6) 抢よび(7)の相転移温度データを Table 3 にまとめる.

次に, 液晶状態のポリマー(4)を液体窒素で急冷して 得られた試料の X 線回折を行った。ポリマー (4c) 抢よ び $(4 \mathrm{~d})$ では，小角側に鋭い反射 $\left(2 \theta=1.87^{\circ}\right.$ およ゙ $\left.1.92^{\circ}\right)$

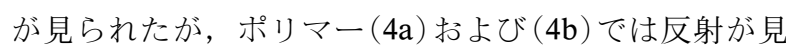
られなかった。しかし，いずれのポリマー(4)でも広角 側でブロードな反射 $\left(2 \theta=15 \sim 30^{\circ}\right)$ が見られ，ポリマー (4c) および $(4 \mathrm{~d})$ では結晶化に由来する反射 $(2 \theta=18$ $\left.25^{\circ}\right)$ が現れた。これらのX 線回折の結果を Table 4 にな とめる. ポリマー $(4 \mathrm{c})$ 抢よび $(4 \mathrm{~d})$ の小角側の反射角から 求めた $d$ 值 $(45.9 \AA(4 \mathrm{c})$ および $47.2 \AA(4 \mathrm{~d}))$ は, ポリ マー $(49.4 \AA(4 \mathrm{c})$ 打よび $55.1 \AA(4 \mathrm{~d}))$ の繰返し単位の長さ より短いことがわかる．以上の結果から，ポリマー(4a) 抢よび $(4 \mathrm{~b})$ はネマチック $(\mathrm{N})$ 相，またポリマー $(4 \mathrm{c})$ 抢よ び $(4 \mathrm{~d})$ はスメクチック $\mathrm{C}\left(\mathrm{S}_{\mathrm{C}}\right)$ 相を，それぞれ形成して いることが示唆される.

引き続いて, HB ポリマー(6)の液晶性を調べた，HB ポリマー(6)は, 2 回目の加熱時の DSC 曲線 (Figure 2) から明らかなように，仕込みモル比に関係なく， $T_{\mathrm{g}}$ に 基づく DSC 曲線のベースラインの変化 $\left(T_{\mathrm{g}}=43 \sim 55^{\circ} \mathrm{C}\right)$ と, 等方相への転移による一つの吸熱ピーク $\left(T_{\mathrm{i}}\right)$ を示 す. 冷却時にも, 対応する一つの発熱ピークおよび $T_{\mathrm{g}}$ に基づくDSC 曲線の変化がみられる. 偏光顕微鏡観察 の結果，加熱および冷却時のいずれにおいても， $T_{\mathrm{g}}$ と 吸熱 $\left(T_{\mathrm{i}}\right)$ あるいは発熱ピークの間で液晶相(シュリーレ ンおよびファイン組織)がみられ，これらの HB ポリ マー(6)はいずれも, 安定なエナンチオトロピック液晶
Table 4. X-ray data of linear polymers (4) and HB polymers (6) and (7) quenched from the LC state between $T_{\mathrm{m}}$ and $T_{\mathrm{i}}$

\begin{tabular}{cccc}
\hline \hline No. & $\begin{array}{c}\text { Small angle } \\
2 \theta\left(^{\circ}\right)\end{array}$ & $\begin{array}{c}d \text { Spacing } \\
(\AA)\end{array}$ & $\begin{array}{c}\text { Molecular length } \\
(\AA)\end{array}$ \\
\hline $4 \mathrm{a}$ & - & - & 48.9 \\
$4 \mathrm{~b}$ & - & - & 48.9 \\
$4 \mathrm{c}$ & 1.92 & 45.9 & 49.4 \\
$4 \mathrm{~d}$ & 1.87 & 47.2 & 55.1 \\
6a & 2.02 & 43.6 & 50.1 \\
6b & 1.92 & 45.9 & 50.1 \\
$6 \mathrm{c}$ & 2.38 & 37.1 & 50.1 \\
6d & 1.74 & 50.8 & 50.1 \\
6e & $1.62,3.32$ & 54.6 & 50.1 \\
7a & $1.76,3.48$ & 50.2 & 53.2 \\
7b & 1.73 & 50.1 & 53.2 \\
\hline
\end{tabular}

a) Length of polymer repeating unit.

相を発現した.

これらの HB ポリマー(6)の X 線回折曲線には，小角 側の鋭い反射 $\left(2 \theta=1.62 \sim 2.38^{\circ}\right.$ および $\left.3.32 \sim 3.48^{\circ}\right)$ と広 角側のブロードな反射 $\left(2 \theta=21 \sim 23^{\circ}\right)$ がみられることか ら, スメクチック $\mathrm{A}\left(\mathrm{S}_{\mathrm{A}}\right)$ 相あるいは $\mathrm{S}_{\mathrm{C}}$ 相を形成してい ることが示唆された. Table 4 のX線回折データから，

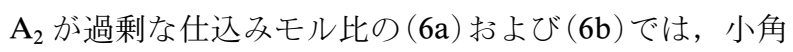
側の反射角から求めた $d$ 值 $(37.1 \sim 45.9 \AA)$ は, 繰返し単 位の長さより短いことから $\mathrm{S}_{\mathrm{C}}$ 相, 逆に $\mathrm{B}_{3}$ が過剰な (6d) 抢よび $(6 \mathrm{e})$ では， $d$ 值が繰返し単位とほぼ同じか若 干長いことから， $\mathrm{S}_{\mathrm{A}}$ 相を形成することが示唆される.

次に, アセチル化処理後の HB ポリマー (7a) および (7b)の液晶性を調べた. Figure 2 からわかるように, 処 理後の DSC 曲線には, 加熱時に $T_{\mathrm{m}}$ を示すことなく, $T_{\mathrm{g}}$ の変化と吸熱ピーク $\left(T_{\mathrm{i}}\right)$ だけがみられ, 冷却時にも 発熱ピークと $T_{\mathrm{g}}$ だけが見られた．偏光顕微鏡観察によ り，加熱時には $T_{\mathrm{g}}$ と吸熱 $\left(T_{\mathrm{i}}\right)$ の間で，また冷却時には $T_{\mathrm{g}}$ と発熱ピークの間でブロークンファン組織および ファイン組織が確認された. Table 4 の X 線回折データ $(2 \theta=1.73 \sim 1.76 \AA$ およよ゙ $3.48 \AA, d=50.1$ および 50.2 A, 繰返し単位の長さ $53.2 \AA$ ) およびポリマーの光学組織 (ブロークンファン組織)の偏光顕微鏡観察の結果から, (7a) および $(7 \mathrm{~b})$ も $\mathrm{S}_{\mathrm{C}}$ 相を形成することが示唆される.

このように, 線状ポリマー $(4 \mathrm{a})$ 抢よび $(4 \mathrm{~b})$ は, エナ ンチオトロピック $\mathrm{N}$ 相，またポリマー $(4 \mathrm{c})$ および $(4 \mathrm{~d})$ は $\mathrm{S}_{\mathrm{C}}$ 相を形成した。しかし, その液晶温度域は狭かっ た.一方, HBポリマー(6)は結晶性が低く, $T_{\mathrm{g}}$ 以上で 非常に安定な, エナンチオトロピック $\mathrm{S}_{\mathrm{A}}$ 相抢よび $\mathrm{S}_{\mathrm{C}}$ 相を形成することが見出された。 $\mathrm{A}_{2}$ モノマーの仕込み モル比が過剰な条件で得られた, HB ポリマーの末端 $\mathrm{OH}$ 基をアセチル化処理すると, 処理後の HB ポリマー (7)は処理前の対応する HB ポリマー(6)より明確な光学 
Table 5. Solution and solid-state absorption and PL spectral data for linear polymers (4), and HB polymers (6) and (7)

\begin{tabular}{cccccccc}
\hline \hline & \multicolumn{3}{c}{ In chloroform } & & \multicolumn{3}{c}{ Solid-state } \\
\cline { 2 - 5 } \cline { 7 - 8 } No. & $\begin{array}{c}\lambda_{\text {max,abs }} \\
(\mathrm{nm})\end{array}$ & $\begin{array}{c}\lambda_{\text {max,PL }} \\
(\mathrm{nm})\end{array}$ & $\begin{array}{c}\text { Stokes } \\
\text { shift } \\
(\mathrm{nm})\end{array}$ & & $\begin{array}{c}\lambda_{\text {max,abs }} \\
(\mathrm{nm})\end{array}$ & $\begin{array}{c}\lambda_{\text {max,PL }} \\
(\mathrm{nm})\end{array}$ & $\begin{array}{c}\text { Stokes } \\
\text { shift } \\
(\mathrm{nm})\end{array}$ \\
\hline 4a & 348.0 & 437.5 & 89.5 & & 359.0 & 455.0 & 96.0 \\
4b & 348.0 & 438.0 & 90.0 & & 359.0 & 455.0 & 96.0 \\
4c & 347.0 & 438.0 & 91.0 & & 355.5 & 455.0 & 99.5 \\
4d & 347.0 & 437.5 & 90.5 & & 355.0 & 455.0 & 100.0 \\
6a & 353.0 & 437.3 & 84.3 & & 363.5 & 457.6 & 94.1 \\
6b & 353.5 & 437.2 & 83.7 & & 358.0 & 456.2 & 98.2 \\
6c & 349.5 & 437.2 & 87.7 & & 347.0 & 448.3 & 101.3 \\
6d & 352.0 & 436.6 & 84.6 & & 358.0 & 459.8 & 101.8 \\
6e & 350.5 & 435.2 & 84.7 & & 346.5 & 459.4 & 112.9 \\
7a & 347.0 & 426.2 & 79.2 & & 342.0 & 452.0 & 110.0 \\
7b & 347.0 & 428.5 & 81.5 & & 338.0 & 453.0 & 115.0 \\
\hline
\end{tabular}

組織を示す傾向がみられた.

\section{3 光学的性質}

線状ポリマー(4)，抢よび HB ポリマー(6) 抢よび (7) のクロロホルム中抢よ゙固体状態での吸収スペクトル, およびその極大吸収波長を励起波長とする蛍光 (PL) スペクトルを測定し, 両者の光学的性質を比較した.

Table 5 にこれらのポリマー(4)，(6) および(7)の吸収お よび PL スペクトルデータをまとめる.いずれのポリ マー(4)においても, 溶液状態の吸収スペクトルには 347 抢よび $378 \mathrm{~nm}$ に極大吸収波長が，また PL スペクトル では 437.5 および $438 \mathrm{~nm}$ に極大発光波長が見られ，微 弱な青色の蛍光の発光が確認された. ストークスシフ トは 89.5〜91 nm であった. 蛍光の量子収率はいずれも 非常に低く，3\%であった。残念ながらこの結果は, HPHPT とセバシン酸ジクロリドから合成した, 線状ポ リマーに対する筆者らの前報の結果と一致する ${ }^{21)}$. ジエ ステルモノマーの構造に無関係に，いずれのポリマー (4) もほとんど同じ吸収抢よび PL スペクトルを示すこ とがわかる. 固体状態での吸収スペクトルでは，(4a)お よび $(4 \mathrm{~b})$ と (4c) および $(4 \mathrm{~d})$ の最大吸収波長には相違が 見られ，(4a)抢よび (4b)が若干長波長側 (359 nm)に極 大吸収波長を示した。これは凝集構造の違いに由来する と推定される. 固体状態でのPL スペクトルには, 吸収 スペクトルの場合と同様, 相違が認められなかった(455 $\mathrm{nm})$ が, 発光強度は溶液状態と同様に非常に弱く, 微弱 な青色の発光が確認された. ストークスシフトは 96〜 $100 \mathrm{~nm}$ であった.

一方, HBポリマー(6)では, クロロホルム中および 固体状態のいずれの場合も, 線状ポリマー(4)の吸収お よびPL スペクトルと類似のスペクトルが観察された が，極大吸収波長は，線状ポリマー(4) とは相違がみら れた.すなわち, クロロホルム中での吸収スペクトルで
は 349.5～353.5 nm に，また固体状態では 346.5～363.5 $\mathrm{nm}$ にそれぞれ極大吸収波長が見られ，特に $\mathrm{A}_{2}$ モノ

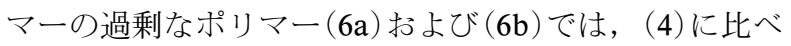
長波長側に吸収がシフトする傾向がみられた。これは, (6a) および (6b)では, ポリマー鎖末端の $\mathrm{OH}$ 基の凝集 により長波長シフトしたものと考えられる. 事実, アセ チル化により末端 $\mathrm{OH}$ 基を処理した場合 ( ( $7 \mathrm{a})$ および $(7 b))$, 処理前に比べ，極大吸収波長は溶液状態 $(347$ $\mathrm{nm})$ では約 $6 \mathrm{~nm}$, また固体状態 (338 および $342 \mathrm{~nm})$ で は 20〜21.5 nm ブルーシフトすることが見いだされた. これは長波長シフトが $\mathrm{OH}$ 基の凝集によることを支持 している.PL スペクトルでは, 溶液および固体状態の いずれでも, 線状ポリマー(4)とほとんど同じ波長で極 大発光波長がみられ，これらのポリマー(6)は微弱な青 色の蛍光を発光することが確認された. 溶液中でのス トークスシフトは 79.2 87.7 nm, 固体状態では 94.1〜 $115 \mathrm{~nm}$ であった。 ストークスシフト值は, 溶液状態よ り固体状態で高いこと, HB ポリマー(6)の方が線状ポ リマー(4)より高いこと, アセチル化処理後(7)の方が処 理前 (6)よりストークスシフト值が大きくなる傾向があ ることがわかる. 蛍光の量子収率は 3\%で, (4) と同様 にかなり低かった.

以上のデータから, 本研究で得られたいずれのポリ マー(4)，(6) 抢よび(7) も，メソゲンの PEPT に由来す るUV-vis 光を吸収して微弱な青色の蛍光を発光するが, 発光性は非常に低く, PEPT は類似構造のDTD に比べ かなり発光性が弱いことがわかる15).これは, 対称的な 構造をもつDTD と異なり, PEPT が非対象なねじれ講 造をもつため, UV-vis 光の吸収はみられるが, 蛍光発光 性は低いものと考えられる. また, ストークスシフト值 はポリマー構造に依存し, 分岐構造をもつ HB ポリマー （6）抢よび (7)の方が, 線状ポリマー(4)よりも高いス トークスシフト值を示す傾向があることが示唆された.

謝 辞 元素分析を担当された江川美智子氏に感謝します。

\section{文献}

1) J. M. J. Fréchet and D. A. Tomalia, "Dendrimers and other dendritic polymers”, Wiley, Chichester, U. K. (2001).

2) D. A. Tomalia and J. M. Fréchet, J. Polym. Sci., Part A: Polym. Chem., 40, 2719 (2002).

3) B. Voit, J. Polym. Sci., Part A: Polym. Chem., 43, 2679 (2005).

4) C. Gao and D. Yan, Prog. Polym. Sci., 29, 183 (2004).

5) C. R. Yates and W. Hayes, Eur. Polym. J., 40, 125 (2004).

6) 佐藤守之, 永島敬介, 山口 勲, 高分子論文集, 63, 656 (2006).

7) M. Sato, Y. Matsuoka, and I. Yamaguchi, J. Polym. Sci., Part A: Polym. Chem., 45, 2998 (2007).

8) L. L. Chapoy, "Advances in Liquid Crystalline Polymers", Elsevier Applied Science, London, U. K. (1985). 
9) H. R. Kricheldorf, Adv. Polym. Sci., 141, 83 (1999).

10) V. A. Greiner and H.-W. Schmidt, "Handbook of Liquid Crystals, vol. 3", D. Demus, J. Goodby, G. W. Gray, and H.-W. Spiess Eds., Wiley-VCH, Weinheim, Germany (1998), p. 1.

11) J.-C. Dubois, P. L. Barny, M. Mauzac, and N. Nöel, "Handbook of Liquid Crystals vol. 3", D. Demus, J. Goodby, G. W. Gray, and H.-W. Spiess Eds., Wiley-VCH, Weinheim, Germany (1998), p. 207.

12）小出直之，坂本国輔，“高分子新素材 One Point-10 液晶 ポリマー”, 高分子学会編集, 共立出版, 東京 (1988).

13) M. Sato, R. Ishii, S. Nakashima, K. Yonetake, and J. Kido, Liq. Cryst., 28, 1211 (2001).

14) M. Sato, S. Nakashima, and Y. Uemoto, J. Polym. Sci., Part A: Polym. Chem., 41, 2676 (2003).

15) M. Sato, Y. Tada, S. Nakashima, K. Ishikura, M. Handa, and K. Kasuga, J. Polym. Sci., Part A: Polym. Chem., 43, 1511 (2005).

16) M. Sato and Y. Uemoto, Macromol. Rapid Commun., 21, 1220 (2000).

17) M. Sato, M. Notsu, S. Nakashima, and Y. Uemoto, Macromol. Rapid Commun., 22, 681 (2001).
18) M. Sato, M. Notsu, and S. Nakashima, Liq. Cryst., 31, 1195 (2004).

19) M. Sato, R. Ohta, M. Handa, and K. Kasuga, Liq. Cryst., 29, 1441 (2002).

20) M. Sato and Y. Kitani, Liq. Cryst., 30, 1109 (2003).

21) M. Sato and R. Ohta, Liq. Cryst., 34, 296 (2007).

22) S. Nakashima, M. Sato, I. Yamaguchi., Polym. Inter., in press.

23) S.-H. Choi, N.-H. Lee, S. W. Cha, and J.-I. Jin, Macromolecules, 34, 2138 (2001).

24) S.-W. Hahn, Y.-K. Yun, J.-I. Jin, and O. H. Han, Macromolecules, 31, 6417 (1998).

25) H. R. Kricheldorf, T. Stukenbrock, and C. Friedrich, J. Polym. Sci., Part A: Polym. Chem., 36, 1397 (1998).

26) A. Reina, A. Gerken, U. Zemann, and H. R. Kricheldorf, Macromol. Chem. Phys., 200, 1784 (1999).

27) M. Murali and A. B. Samui, J. Polym. Sci., Part A: Polym. Chem., 44, 53 (2006).

28）三嶋祐康, 中嶋 淳, 佐藤守之, 山口 勲, 第 56 回高分子 学会年次大会予稿集 (京都), 2pf112 (2007).

29) P. J. Flory, J. Am. Chem. Soc., 74, 2718 (1952).

30) Q. Lin and T. E. Long, Macromolecules, 36, 9809 (2003).

Preparation and Properties of New $\mathbf{A}_{2}+B_{3}$ Type Hyperbranched Polymers Containing Heterocyclic Mesogen Units in the Interior Moriyuki Sato ${ }^{* 1}$, Atsushi NaKashima ${ }^{* 1}$, and Isao YamaGuCHI ${ }^{* 1}$

${ }^{* 1}$ Department of Material Science, Faculty of Science and Engineering, Shimane University (1060 Nishikawatsu, Matsue 690-8504, Japan)

New structure-controlled $\mathrm{A}_{2}+\mathrm{B}_{3}$ type hyperbranched (HB) polymers containing a phenylstilbene analogue (PEPT) of 1,3,4-thiadiazole as mesogen in the interiors were prepared by solution polycondensation from dioxydiundecanol derivative of PEPT $\left(\mathrm{A}_{2}\right)$ and trimesic acid trimethyl ester $\left(B_{3}\right)$ at various feed molar ratios $\left(A_{2} / B_{3}\right)$ and their liquid crystalline $(L C)$ and optical properties were examined. The structure of polymers changed depending on the feed molar ratios. Their number-average molecular weights increased after acetylation of terminal $\mathrm{OH}$ groups of the polymers. The $\mathrm{HB}$ polymer prepared with a feed molar ratio of $\mathrm{A}_{2} / \mathrm{B}_{3}=3 / 2$ had the maximum molecular weight. All HB polymers are soluble in organic solvents and formed enantiotropic smectic LC phases above their glass transition temperatures. The UV-vis and photoluminescent (PL) spectra of polymers displayed absorption and emission maxima in the blue region, but the fluorescence intensities were extremely weak. The properties of HB polymers were also compared with those of the corresponding linear polymers. KEY WORDS $\mathrm{A}_{2}+\mathrm{B}_{3}$ Type Hyperbranched Polymer / Heterocyclic Mesogen Unit / Liquid Crystalline Property / Optical Property /

Linear Polymer /

(Received May 28, 2007: Accepted August 27, 2007)

[Kobunshi Ronbunshu, 64(12), 929-936 (2007)] 